\title{
СЕРLЯ «Право»
}

УДК 340.12.12:342.737

https://doi.org/10.52058/2708-7530-2021-2(8)-303-314

Комнатний Сергій Олександрович кандидат педагогічних наук, Національна академія внутрішніх справ, Солом'янська площа, 1, Київ, 02000, e-mail: komnatniy@ukr.net, тел.: (095) 280-24-80, https://orcid.org/0000-0002-21242047

\section{ЗАКОНОДАВЧЕ ВРЕГУЛЮВАННЯ ДІЯЛЬНОСТІ ЖИТЛОВИХ КООПЕРАТИВІВ В УКРАЇНІ, МІЖНАРОДНА ПРАКТИКА}

Анотація. Житлове питання було і залишається одним з важливих питань для громадян України. Рівень забезпеченості житлом в нашій країні є в декілька разів менший, ніж показник в країнах Європи та складає 23 квадратних метри на кожного мешканця. Актуальним питанням сфери житлової політики нашої держави є створення дієвих механізмів та форм створення та обслуговування житлового фонду. Житлово-будівельні кооперативи, як одна з форм забезпечення житлом громадян існували на території України ще з початку минулого століття але в теперішній час, не є активними формами, якими користуються громадяни. Це пов'язане, перш за все, з застарілою та колізійною нормативно-правовою базою, яка регулює суспільно-правові відносини під час створення та функціонування кооперативів в Україні. В той же час, дана форма житлового забезпечення $\epsilon$ актуальною і достатньо розвиненою в країнах Європи. Тому постає необхідність наукового опрацювання системи нормативно-правових актів, в галузі житлової політики, яка регулює діяльність кооперативів, дослідження їхнього впливу на розвиток та захист житлових прав громадян та переосмислення їхньої філософсько-правової парадигми. У статті проведено аналіз досвіду розвинених країн зі створення та діяльності житлових кооперативів. Наведено основні різновиди житлових кооперативів, які мають розповсюдження у світовій практиці. Визначено особливості житлових кооперативів у деяких країнах світу: Італія, Норвегія, Польща, Естонія, США. Дослідження має на меті проаналізувати діючу законодавчу базу створення, регулювання діяльності житлових кооперативів в Україні. Визначено нормативно-правові акти, що потребують вдосконалення. Окреслено основні недоліки та прогалини законодавства України, 
що потребують врегулювання, а також правові перепони, що стримують розвиток інституту житлових кооперативів в Україні. В дослідженні пропонується визначити основні проблемні питання, що можуть виникнути при створенні та діяльності житлових кооперативів від моменту створення до моменту завершення будівництва житла. Досліджено питання, чи може бути житловий кооператив ефективним інструментом при будівництві житла за діючої в Україні нормативноправової бази. Запропоновано напрями, які $\epsilon$ найбільш ефективними та перспективними для розвитку інституту житлових кооперативів в Україні, визначено напрямки вдосконалення законодавства, що регулює питання діяльності житлових кооперативів в Україні.

Ключові слова. Житлові кооперативи, обслуговуючі кооперативи, будівництво житла, механізми організації будівництва житла.

Komnatniy Serhii Oleksandrovych PhD in Pedagogical Sciences, National Academy of Internal Affairs, Solomianska Square, 1, Kyiv, 02000, e-mail: komnatniy@ukr.net, tel.: (095) 280-24-80, https://orcid.org/0000-0002-2124-2047

\section{LEGISLATIVE REGULATION OF HOUSING COOPERATIVES IN UKRAINE, INTERNATIONAL PRACTICE}

Abstract. The housing issue remains to be one of the most relevant problems for the Ukrainian citizens. The level of accommodation with housing in Ukraine is several times lower than in Europe and is 23 square meters per capita. An urgent issue in the field of housing policy of our country is the establishment of effective mechanisms and forms of creation and maintenance of housing. Housing cooperatives, as one of the forms of providing housing for citizens, have existed in Ukraine since the beginning of the last century, but now, not being used as active form by citizens. This is primarily due to the outdated and conflicting legal framework governing public relations during the establishment and operation of cooperatives in Ukraine. At the same time, this form of housing is relevant and well developed in European countries. Therefore, there is a need for scientific elaboration of the system of legal acts in the field of housing policy, which regulates the activities of cooperatives, the study of their impact on the development and protection of housing rights, and reconsideration their philosophical and legal paradigm. The article analyses the experience of developed countries in the establishment and operation of housing cooperatives. The main types of housing cooperatives, which are widespread in the world practice, are given. The characteristics of housing cooperatives in some countries of the world are determined: Italy, Norway, Poland, Estonia, and USA. The study aims to analyse the current legal framework of the establishment and regulation of housing cooperatives in Ukraine. Regulations that need 
improvement have been identified. The main shortcomings and gaps in the legislation of Ukraine that need to be regulated, as well as legal obstacles that hinder the development of the institution of housing cooperatives in Ukraine are outlined. The study proposes to identify the main problematic issues that may arise in the establishment and operation of housing cooperatives from the moment of creation to the completion of housing construction. The question of whether a housing cooperative can be an effective tool in housing construction under the current regulatory framework in Ukraine has been studied. The directions which are the most effective and perspective for development of the institute of housing cooperatives in Ukraine are offered, the directions of perfection of the legislation regulating questions of activity of housing cooperatives in Ukraine are defined.

Keywords. Housing cooperatives, service cooperatives, housing construction, mechanisms for organizing housing construction.

Постановка проблеми. Кожна країна прагне створити сприятливі умови для життя та розвитку своїх громадян. Україна, яка наразі стоїть на шляху до становлення як розвинена європейська країна, має перед собою аналогічне завдання. Вирішення житлового питання є одним із ключових кроків на такому шляху. Житлова політика нашої країни останніх часів здебільшого будувалася на принципах політичної волі, а не на принципах логічності, послідовності та результативності, які мають супроводжувати будь-яку політику держави. Те, що ми маємо на сьогодні, - це радянський Житловий кодекс і Концепція житлової політики, схвалена ще 25 років тому. Житлове законодавство реформувалося i змінювалося точково, хаотично, відповідно маємо застарілі норми, навіть атавізми законодавства, поряд із законодавством, сформованим на принципах європейського. Інститут житлового кооперативу, який сьогодні існує в нашій країні, відповідно до законодавства, що регулює питання створення та функціонування житлового кооперативу, також $\epsilon$ уособленням поєднання застарілих норм і нового сучасного законодавства.

Тому $\epsilon$ необхідність вивчення світового досвіду створення житлових кооперативів, порівняння 3 історичним досвідом, який ми маємо, і в результаті напрацювання нових пропозицій щодо реформування законодавства, яке регулює діяльність житлових кооперативів в Україні.

Аналіз останніх досліджень і публікацій. Важливі аспекти формування i діяльності житлових кооперативів як механізмів забезпечення громадян доступним житлом досліджувалися такими українськими вченими, як О. Непомнящий, О. Кучеренко, В. Ніколаєв, В. Фатула та іншими.

Мета статті. У статті пропонується дослідити історичний аспект створення житлових кооперативів на території України: розвиток житлових кооперативів на 
території сучасної України на початку 20 століття, їх різновиди, механізми державної фінансової підтримки, відновлення житлових кооперативів у Радянському Союзі в післявоєнний період та за часів незалежної України. Також метою дослідження $є$ еволюція розвитку поняття житлового кооперативу, діючі моделі житлових кооператив в Україні як об'єднань громадян для досягнення певної спільної мети.

Методологічний інструментарій обрано з урахуванням поставленої мети, специфіки предмета й об'єкта дослідження через системний порівняльноправовий аналіз світової практики у сфері створення та існування житлових кооперативів, дослідження ефективності існуючих форм існування житлових кооперативів, з урахуванням історичних, економічних та правових аспектів.

Виклад основного матеріалу. Перший етап - початок 20 століття. Саме цей період можна охарактеризувати як період зростання кількості міського населення. Розпочався процес урбанізації. Сільське населення поступово переїздило до міст, відповідно, зростала потреба у житлі. За значної потреби власники житла в містах підвищували ціни на оренду. Виникли історичні передумови для запровадження ефективних i доступних механізмів вирішення житлового питання. Перші кооперативні об’єднання було створено, звичайно, у тогочасних великих містах Києві, Одесі, Бердянську, Миколаєві, Херсоні та Житомирі [1].

За умови наявності власних коштів, що складали не менше 40\% від вартості будівництва, члени кооперативу могли розраховувати на отримання кредиту. Ставка за таким кредитом становила 6\% річних. На початку 1909 року на території сучасної України діяли близько 60 житлових кооперативів [2].

Другий етап - перші роки після захоплення влади більшовиками. Тоді, на початку 20-их років XX століття, у містах так само існували проблеми із житловим забезпеченням. Коштів у держави для вирішення житлового питання для всіх потребуючих не вистачало, потрібно було залучати кошти громадян. Тоді було ухвалене відповідне законодавство, що врегулювало діяльність житлової кооперації в країні. Кооперативи створювалися як житлово-орендні та житловобудівельні. Житлово-орендні кооперативи отримували житловий будинок в оренду строком до 9 років. Члени такого кооперативу мали право передавати отримане житло в суборенду та, в разі необхідності, отримати кредит на капітальний ремонт такого будинку. Житлово-будівельні кооперативи створювалися для будівництва житла за умови, що члени такого кооперативу вносили власний грошовий вступний внесок. Також була передбачена можливість кредитування членів кооперативу за відсотковою ставкою не більшою 1 відсотка річних. Основною особливістю цього періоду було те, що, відповідно до чинного на той час законодавства, члени кооперативу могли отримати житло у приватну 
власність, що, звичайно, суперечило ідеології того часу. Тому вже з 1937 року всі кооперативні будинки стали державною власністю. Можна сказати, що відтоді й до післявоєнного періоду 50-их років розвиток житлової кооперації на території України було призупинено.

Нарешті, третій етап - післявоєнний Радянський Союз i, відповідно, післявоєнна Україна. Країна повернулася до житлової кооперації наприкінці 1950их - на початку 1960-их років.

Ухвалений 1983 року Житловий кодекс врегулював питання створення та діяльності житлово-будівельних кооперативів на законодавчому рівні. Кооперативи будували за рахунок внесків членів такого кооперативу, а також отримували від держави пільги й компенсації. До прикладу, це була позика в обсязі до 90 відсотків вартості такого будівництва, при цьому ставки за користування кредитом складали від 1 до 3 відсотків річних, були запроваджені дотації на комунальні послуги, обслуговування i капітальний ремонт будинків житлово-будівельних кооперативів.

Обсяг житла, збудованого житлово-будівельними кооперативами, на той час складав 6-7 відсотків від загальної збудованої житлової площі, або близько 8 тисяч житлових будинків, у яких мешкали понад 1,5 млн осіб.

Світова практика житлових кооперативів дещо відрізняється від зрозумілого для нас застосування поняття «житловий кооператив».

Світовий досвід житлової кооперації розвивався за трьома основними напрямками: житлово-будівельні ощадні каси, житлові кооперативи як кондомініуми, та власне житлові кооперативи.

Житлово-будівельні ощадні каси досить успішно функціонували в Німеччині, було кілька спроб застосувати цей механізм і в Україні. Проте результативними ці спроби не стали. Уряд України 2010 року навіть ухвалив Концепцію розвитку житлової кооперації та запровадження житлово будівельних ощадних кас. Будівельно-ощадна каса, за своєю суттю, це фінансова установа, що залучає кошти громадян. За рахунок цих коштів кредитуються вкладники. При цьому може мати місце і державна підтримка, яка може полягати, до прикладу, у вигляді виплати певного доходу на внески. Слід відзначити, що цей механізм застосовується в Австрії, Франції, Словаччині, Чехії, Хорватії, Словенії, Румунії.

Такий механізм функціонування житлового кооперативу, як кондомініум, передбачає, що у загальній власності кондомініуму перебуває, до прикладу, підвал, місце для паркування машин, ліфти, сходи, балкони, зелені насадження, басейни тощо. Власники товариства спільно розпоряджаються таким майном, що може дати їм змогу навіть отримувати певний дохід від здавання такого майна в оренду. Такий вид кооперативу також характерний для Німеччини і Естонії.

Житлово-будівельні кооперативи, що створюються саме для будівництва 
житла, є характерними також для Іспанії, Швеції, Великобританії, Італї.

Розглянемо, як врегульовуються питання житлових кооперативів у деяких країнах світу.

У Італії існують два типи житлових кооперативів: звичайні житлові кооперативи і соціальні житлові кооперативи.

Ключовими характеристиками обох типів $\epsilon$ те, що членство в житлових кооперативах відкрито для всіх, хто бажає жити в кооперативній житловій одиниці. Кожна особа, зацікавлена в кооперативному житлі, купує долю, яка надає людині право голосу, право бути включеним до списку очікування і право бути поінформованим про те, коли житло стане доступним. Усі житлові кооперативи повинні робити певні внески до фонду національного розвитку.

Для традиційних житлових кооперативів характерним $\epsilon$ те, що житлові одиниці належать окремим їхнім членам на праві власності. Паї продаються індивідуальним членам за ціною трохи нижчою за ринкову з урахуванням спеціальних державних субсидій. Деякі обмеження відносно пайової участі встановлюються при перепродажу на термін не менший за 20 років. Соціальні житлові кооперативи - це фактично оренда. Характеризуються вони такими особливостями: орієнтовані на людей з особливими потребами, як перестарілі, інваліди, люди 3 низькими доходами. Житло залишається у власності кооперативу, при цьому окремі члени кооперативу, по суті, орендують житло у кооперативу. При проектуванні будівель враховуються потреби цільової групи.

Для Норвегії характерним є те, що кожен кооператив у середньому управляє близько 50 будинками. Щоб стати учасником кооперативу, потрібно придбати акції, які реалізовуються на відкритому ринку за повною ринковою вартістю, причому члени кооперативних житлових асоціацій мають право переважного придбання. Кожен член кооперативу має один голос, незалежно від кількості або вартості акцій. Місцева влада має право на придбання 10\% квартир у житловобудівельних кооперативах [3].

У Польщі, попри те, що житлові кооперативи вже не $є$ основними постачальниками житла, близько 11 мільйонів громадян мешкають у кооперативних будинках. Хоч багато великих житлових кооперативів були розділені на менші об'єкти власності, житлові кооперативи навіть сьогодні можуть бути величезними організаціями, налічуючи до 100000 членів на кооператив. Спочатку в Польщі існувало два типи житлової кооперації: на умовах власності та на умовах оренди. Сьогодні всі кооперативи $є$ кооперативами власників. Ключовими характеристиками польських житлових кооперативів є:

- індивідуальна власність, яка обмежена одиницями, тоді як кооператив володіє землею та будівлею,

- учасники купують акції, еквівалентні повній вартості будівництва їх 
одиниці,

- власники кооперативів можуть вийти з кооперативу, коли сплачують повну вартість будівництва, ці власники можуть створити ОСББ для управління,

- члени можуть продати своє майнове право, кооператив має право прийняти нового члена.

Житлові кооперативи або квартирні асоціації в Естонії - це некомерційні організації, створені для управління зонами загального користування житлового будинку. Одиниці належать окремим членам - власникам, які вносять квартирну плату відповідно до фактичних витрат, продаж житла регулюється ринком, кооперативи можуть управляти кількома житловими будинками [4]

У незалежній Україні на початку 90-х років житлово-будівельні кооперативи продовжували існувати здебільшого як обслуговуючі кооперативи, фактично як аналоги сучасних об’єднань співвласників житлового будинку.

Ринок житла в Україні пропонує таку вартість одного квадратного метра житла, що пересічному громадянину, який отримує навіть середню заробітну платню, самостійно заощадити і придбати житло - щось зі сфери фантастики.

Враховуючи спрямованість нашої країни на досягнення європейських стандартів життя, виконання Цілей сталого розвитку, необхідно вишукувати можливості для здешевлення для наших громадян вартості соціальних благ, в тому числі житла. Одним 3 варіантів здешевлення вартості житла для кінцевого споживача, враховуючи історичний аспект питання, є житловий кооператив. А чи дійсно це може бути реалізовано за сучасної нормативно-правової бази України, спробуємо дослідити.

Закон України «Про правонаступництво України» визначив, що Закони, інші нормативні акти, що були ухвалені верховною Радою УРСР діють на території України в частині, що не суперечить Законам України, ухваленим після набуття Незалежності.

Отже, чинна законодавча база України про кооперацію частково базується на нормах законодавства, прийнятого вже в незалежній Україні, але частково й на нормах, які діяли за часів Радянського Союзу. Навіть норми, прийняті за часів Незалежності України саме щодо створення і діяльності кооперативів, тривалий час не оновлювалися і не враховують ані нового законодавства України, ані сучасних вимог і потреб суспільства.

Основні норми щодо діяльності кооперативів містяться в Цивільному кодексі України, Житловому кодексі УРСР, а також у спеціальній правовій базі: зокрема, Законі України «Про кооперацію», Примірному статуті житлово-будівельного кооперативу 1985 року, Правилах утримання жилих будинків та прибудинкових територій 2005 року.

Закон України «Про кооперацію» зазначає, що законодавство про кооперацію 
базується на нормах Конституції України і Цивільного кодексу України, Закону України "Про сільськогосподарську кооперацію", інших нормативно-правових актах з питань кооперації.

Кооперативом, відповідно до статті 1 Закону України «Про кооперацію», є юридична особа, утворена фізичними та/або юридичними особами, які добровільно об'єдналися на основі членства для ведення спільної господарської та іншої діяльності з метою задоволення своїх економічних, соціальних та інших потреб на засадах самоврядування.

Господарським кодексом України визначено кооперативи як добровільні об'єднання громадян з метою спільного вирішення ними економічних, соціальнопобутових та інших питань.

Отже, Господарський кодекс прямо вказує, що кооператив може бути створений виключно громадянами, тобто фізичними особами. При цьому Закон України «Про кооперацію» передбачає таку можливість і для юридичних осіб. Такі ж висновки можна зробити з Примірного статуту житлово-будівельного кооперативу 1985 року.

Маємо перше питання: хто суб'єктно може бути членом житловобудівельного кооперативу.

Чинним Житловим кодексом установлено, що членами житловобудівельного кооперативу можуть бути громадяни, які постійно проживають у даному населеному пункті, перебувають на обліку бажаючих вступити до житлово-будівельного кооперативу та внесені до єдиного державного реєстру громадян, які потребують поліпшення житлових умов. Подібні норми також містяться у Примірному статуті житлово-будівельного кооперативу.

Тобто діюча норма Житлового кодексу визначає, що членами житлового кооперативу можуть бути лише ті громадяни, що потребують поліпшення житлових умов, тобто стоять на так званій «квартирній черзі» для отримання безоплатного житла. В сучасних умовах, коли претендувати на отримання безоплатного житла від держави, на мою думку, мають право лише найбільш соціально незахищені верстви населення, прив'язка до квартирної черги при створенні житлово-будівельного кооперативу є нонсенсом. Звісно, при створенні житлово-будівельних кооперативів сьогодні інвестори таких норм не дотримуються.

У статті 2 Закону України "Про кооперацію" визначено, що "кооператив" це юридична особа, утворена фізичними та/або юридичними особами, які добровільно об'єдналися на основі членства для ведення спільної господарської та іншої діяльності з метою задоволення своїх економічних, соціальних та інших потреб на засадах самоврядування.

Маємо друге питання: чи має бути перебування на квартирному обліку 
обов’язковою вимогою для вступу до кооперативу.

За Житловим кодексом, житлово-будівельні кооперативи організовуються при виконавчих комітетах місцевих рад народних депутатів, при підприємствах, установах і організаціях.

Водночас, відповідно до Господарського кодексу України, кооперативи створюються як добровільні об'єднання громадян.

Стаття 37 Закону України «Про кооперацію» містить чітку заборону на втручання органів державної влади і органів місцевого самоврядування у фінансово-господарську та іншу діяльність кооперативних організацій, крім випадків, прямо передбачених законом.

Маємо третє питання: чи дійсно житлово-будівельний кооператив - це добровільне об’єднання.

Всі три порушені питання сьогодні не мають однозначної відповіді.

Прикінцеві положення Закону України «Про кооперацію» зобов’язують Кабінет Міністрів України протягом року з дня набрання чинності цим законом вжити заходів, спрямованих на приведення у відповідність до норм цього закону інших нормативно-правових актів. Такі своєчасні дії могли б вирішити всі порушені питання, та сьогодні відповідні зміни не внесені. Відсутність чіткого регулювання має негативні наслідки для громадян. До прикладу, існує судова практика, за якої саме на тій підставі, що при створенні житлово-будівельного кооперативу не було дотримано вимог Житлового кодексу, зокрема, члени кооперативу не перебували на обліку громадян, що потребують поліпшення житлових умов, суд ухвалив рішення про скасування реєстрації такого кооперативу.

Як ми дослідили вище, житлово-будівельні кооперативи в Україні можуть бути створені та діяти як під час самого будівництва житлового будинку членами кооперативу, так і після завершення будівництва - як обслуговуючий кооператив, аналог об'єднання співвласників житлового будинку. Тобто можна виділити обслуговуючі та споживчі житлово-будівельні кооперативи.

Відповідно до статті 19 Закону України «Про кооперацію», кооператив є власником будівель, споруд, грошових та майнових внесків його членів, виготовленої продукції, доходів, отриманих від іiі реалізації та провадження іншої передбаченої статутом діяльності, а також іншого майна, придбаного на підставах, не заборонених законом. Отже, нерухомість, що споруджується за рахунок коштів житлово-будівельного кооперативу, буде власністю кооперативу.

Таким чином, після завершення будівництва і здачі об'єкта в експлуатацію житлово-будівельний кооператив є власником будинку. Отже, на стадії, що передує передачі квартир інвестору, ЖБК має повне право розпоряджатися усім будинком, включаючи квартири, на законній підставі, навіть передати в заставу. 
Також незахищеними залишаються права інвесторів (членів кооперативу) в разі ліквідації кооперативу, у тому числі у зв’язку з банкрутством. Підстави для визнання банкрутом кооперативу можуть з'явитися як до, так і після завершення будівництва.

Відповідно до статті 13 Закону «Про кооперацію», членство в кооперативі припиняється в тому числі у зв’язку з припиненням діяльності кооперативу.

У судовій практиці існує багато справ про визнання банкрутом житловобудівельних кооперативів за заявами як самих житлово-будівельних кооперативів, так і кредиторів за заборгованістю.

У цьому контексті неоднозначним є питання: яким чином учасник житловобудівельного кооперативу, який повністю вніс свій пай, зможе стати власником новозбудованої квартири. Тобто як документально оформити «викуп» квартири, передбачений Цивільним кодексом України.

Цікавим також є питання оподаткування.

Податковим кодексом України визначено, що 3 першого числа місяця, наступного за місяцем, в якому відповідно до закону здійснено прийняття в експлуатацію закінченого будівництвом житлового будинку, i такий житловий будинок споруджувався або придбавався житлово-будівельним (житловим) кооперативом, дачні (дачно-будівельні), садівничі та гаражні (гаражно-будівельні) кооперативи (товариства) мають право на отримання статусу неприбутковості.

Проте Податковим кодексом не визначено, що в майбутньому такий житлово-будівельний кооператив не матиме права будувати новий будинок уже в статусі неприбутковості.

Звісно, є офіційна думка податкової служби, яка зазначає, що при отриманні статусу неприбутковості такий кооператив позбавляється права в статусі неприбуткової організації здійснювати будівництво інших об’єктів.

На мою думку, це питання не є чітко визначеним і може бути предметом спору в судах.

Цікавим також $\epsilon$ питання оподаткування податком на додану вартість операцій, пов'язаних 3 будівництвом багатоквартирного житлового будинку новоствореним житлово-будівельним кооперативом.

Відповідно до Податкового кодексу, звільняються від оподаткування ПДВ операції з постачання житла (об’єктів житлового фонду), крім їх першого постачання. Що саме має розглядатися як перше постачання - послуги 3 будівництва житла, що надаються на замовлення кооперативу, чи передача житла членам кооперативу?

Однозначну відповідь на це питання можна дати, лише чітко виклавши норми Податкового кодексу.

Висновки. Враховуючи велику кількість громадян України, що потребують 
підтримки у вирішенні житлового питання, а також взяті Україною на себе зобов'язання перед міжнародною спільнотою, зокрема, щодо виконання Глобальних цілей сталого розвитку, житлово-будівельні кооперативи можуть розглядатися як ефективний інструмент для створення сприятливих умов здешевлення вартості будівництва житла для громадян. Чинне законодавство України містить низку суттєвих прогалин і рудиментів радянського законодавства та потребує вдосконалення та доопрацювання. Тому необхідно:

розробити окремий закон, який повинен врегулювати питання особливостей створення i діяльності житлово-будівельного кооперативу, зокрема, чітко визначити права та обов'язки членів кооперативу, момент набуття права власності на житло членами кооперативу, обслуговування в майбутньому такого житлового будинку тощо;

до прийняття нового Житлового кодексу України внести зміни до його норм, врегулювавши питання створення та членства у житлово-будівельних кооперативах, виключивши норми щодо необхідності перебування членів кооперативу на обліку тих, хто потребує поліпшення житлових умов, а також інші застарілі положення;

внести зміни до Податкового кодексу, передбачивши прямі норми, які дозволять житлово-будівельним кооперативам діяти в статусі неприбутковості, врегулювавши питання сплати податку на прибуток, а також податку на додану вартість.

\section{Лimepamypa:}

1. Кацюба К.В., Дорошенко Р.В., Шанталій К.С., Проблемні аспекти створення об'єднання співвласників багатоквартирних будинків.// Юридичний науковий електронний журнал, № 7/2020. DOI https://doi.org/10.32782/2524-0374/2020-7/24;

2. Молдованов Д.В., Об'єднання співвласників багатоквартирного будинку як суб'єкт ринку альтернативної енергетики.// Прикарпатський юридичний вісник, Випуск 2(27), 2019. DOI https://doi.org/10.32837/pyuv.v0i2(27).199;

3. Aernouts Nele, Michael Ryckewaert, Reproducing housing commons. Government involvement and differential commoning in a housing cooperative.//Housing Studies 34(1):1-19 February 2018. DOI https://doi.org/10.1080/02673037.2018.1432756;

4. Букіашвілі В. О. Житлова політика як елемент соціальної політики держави: аналіз вітчизняного та закордонного досвіду // Економіка будівництва і міського господарства, том 5, номер 3, 2009;

\section{References:}

1. Katsiuba, K.V., Doroshenko, R.V., Shantalii, K.S. (2020). Problemni aspekty stvorennia obiednannia spivvlasnykiv bahatokvartyrnykh budynkiv [Problematic aspects of creating an association of co-owners of apartment buildings]. Yurydychnyi naukovyi elektronnyi zhurnal - Legal Scientific Electronic Journal, 7, 102-105. DOI https://doi.org/10.32782/2524-0374/2020-7/24 [in Ukrainian]. 
2. Moldovanov, D.V. (2019). Obiednannia spivvlasnykiv bahatokvartyrnoho budynku yak subiekt rynku alternatyvnoi enerhetyky [Association of co-owners of an apartment building as a subject of the alternative energy market]. Prykarpatskyi yurydychnyi visnyk - Prykarpattya Legal Bulletin, 2(27), 103-107. DOI https://doi.org/10.32837/pyuv.v0i2(27).199 [in Ukrainian].

3. Aernouts, N., Ryckewaert, M. (2018). Reproducing housing commons. Government involvement and differential commoning in a housing cooperative. Housing Studies, 34(1), 92-110. DOI https://doi.org/10.1080/02673037.2018.143275 [in English].

4. Bukiashvili, V. O. (2009). Zhytlova polityka yak element sotsialnoi polityky derzhavy: analiz vitchyznianoho ta zakordonnoho dosvidu [Housing policy as an element of social policy of the state: analysis of domestic and foreign experience]. Ekonomika budivnytstva i miskoho hospodarstvaEconomics of Construction and Municipal Economy, 5(3), 141-146 [in Ukrainian]. 